\title{
Die skepping van welstand in die skool se kurrikulum vir natuurwetenskappe: Die twee vermiste skakels
}

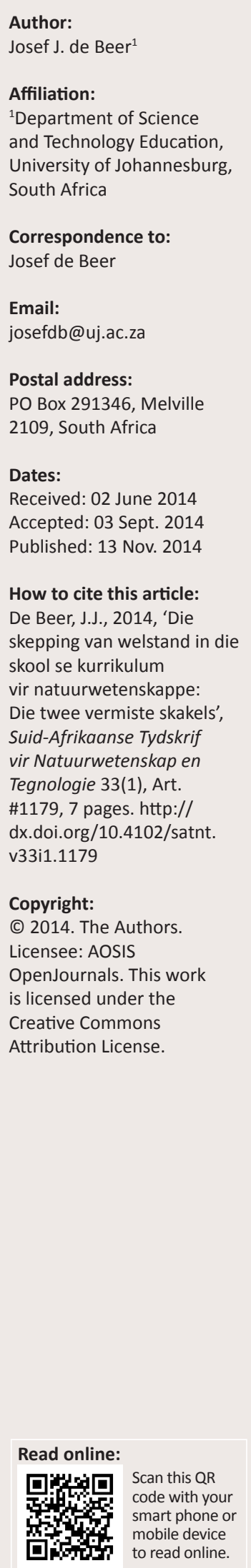

Hierdie artikel werp lig op twee vermiste skakels wat daartoe lei dat die welstand van leerders en 'n waardering vir 'n meer holistiese siening van gesondheidsorg nie voldoende aandag kry in die kurrikula vir natuurwetenskappe op skool nie. Eerstens word gesondheidsorg in die kurrikula vir natuurwetenskappe (Senior Fase) en lewenswetenskappe (Verdere Opvoeding en Opleiding) vanuit 'n baie reduksionistiese perspektief beskou (ook deur die betrokke onderwysers), en leerders ontwikkel dus nie waardering vir die holistiese aard daarvan nie. Tweedens word daar betoog vir meer klem op die affektiewe domein in die natuurwetenskappeklaskamer, en groter fokus op inheemse kennisstelsels, wat wel holisme omvat. Die artikel bied praktiese voorbeelde van hoe die grense tussen die natuurwetenskap en die metafisika oorgesteek kan word, sonder om die doktrines wat die aard van natuurwetenskappe beskryf, in gedrang te bring. Voorts word aangedui hoe sodanige oorsteek van grense kan lei tot 'n meer genuanseerde beeld en waardering vir holistiese gesondheidsorg onder skoolleerders.

Creating wellness in the school natural sciences curriculum: The two missing links. This article sheds light on two missing links in the science school curriculum which result in learners' wellness and appreciation for a holistic view of health not being adequately addressed. Firstly, in the natural sciences curriculum (Senior Phase) and life sciences curriculum (Further Education and Training), health and wellness are often viewed (also by the teachers) from a reductionist perspective, which results in learners not appreciating the holistic nature of healthcare. Secondly, I argue for greater emphasis on the affective domain in the science classroom, and a stronger focus on indigenous knowledge systems which do embrace holism. The article provides practical examples of border crossing between the natural sciences and metaphysics, without ignoring the tenets of the nature of science. The author shows how such border crossing could result in learners developing a more nuanced understanding of and appreciation for holistic wellness.

\section{Inleiding}

\section{Holisme, holistiese gesondheid en die huidige skoolkurrikulum}

'n Mens kan tereg wonder wat Jan Smuts, wat allerweë beskou word as die vader van holisme, van die huidige stand van die kurrikula vir natuurwetenskappe, lewenswetenskappe en fisiese wetenskappe op skool, en veral die implementering daarvan, sou sê. Smuts was van mening dat die onderverdeling van die wetenskap in streng afgebakende en onafhanklike dissiplines sal lei tot ' $n$ verswakking van die potensiaal om menslike probleme maksimaal te verstaan en op te los (Cowling 2014). Smuts (1926) voer aan:

Matter, life, and mind ... should be seen as greater emergent wholes based on greater complexification that consequently interpenetrated and informed each other. Holism is the tendency in nature to form wholes that are greater than the sum of the parts. [Materie, lewe, en intellek ... moet gesien word as groter gehele wat te voorskyn kom, met as basis 'n groter kompleksiteit wat mekaar infiltreer en inlig. Holisme is die neiging in die natuur om gehele te vorm wat groter is as die som van die dele.] (p. 342, [author's own translation])

Holistiese gesondheid is 'n benadering wat fokus op die mens as geheel, eerder as op 'n spesifieke siektetoestand of bepaalde liggaamsdeel wat geïnfekteer is. Dit is 'n benadering wat die verweefdheid tussen die brein (kognitief), liggaam en gees beklemtoon (Collinge 1996). In holistiese gesondheid val die klem op die mens as liggaam én gees, en die keuses van hoe daar in die omgewing opgetree word. Die meeste antieke genesingsisteme beklemtoon die noodsaaklikheid daarvan om in harmonie met die omgewing te leef, en om gesonde keuses te maak. Sedert die tyd van Sokrates weerklink die refrein op dat die deeltjie nie gesond kan wees as dit nie goed met die geheel gaan nie. Inheemse kennisstrukture word ook deur hierdie holisme gekenmerk. In 
beide die inheemse Khoisan- en Afrika-kennissisteme staan die metafisiese komponente sentraal (De Beer 2012).

Westerse wetenskap marginaliseer egter dikwels so 'n holistiese uitkyk. Die kurrikulum vir lewenswetenskappe identifiseer mikro-organismes soos virusse, bakterieë en protiste as die draers van siektes, en dikwels word leerders onder die indruk gebring dat 'n mens, ondanks ongesonde leefstylkeuses, skotvry daarvan kan afkom, omdat die moderne wetenskap en medisyne enige probleem sal regstel. Volgens so ' $n$ ingesteldheid is ' $n$ mikro-organisme die enigste rede waarom iemand siek word, en word die individu en sy ongesonde leefstyl van blaam onthef.

Hierdie artikel betoog vir 'n meer holistiese uitkyk in die natuurwetenskappe-klaskamer, en sterker fokus op die affektiewe domein, wat dikwels as een van die vernaamste vermiste skakels in wetenskaponderrig beskou kan word (De Beer 1990). Die twee argumente wat voorgehou word, is dat (1) onderwysers in die natuurwetenskappe moet verwys na holistiese gesondheid, om 'n waardering daarvoor by leerders te ontwikkel, en (2) dat groter klem op inheemse kennisstrukture in die klaskamer sal lei tot beter begrip van holisme by leerders, en die rol van 'n holistiese uitkyk op die skepping van welstand. Die algemene betoog is dat die insluiting van inheemse kennis in die kurrikulum kan lei tot groter welstand onder leerders.

\section{Metodologie}

Dié is 'n teoretiese besinning aangaande die sukses waarmee welstand benader word in die kurrikulum vir natuurwetenskappe op skool. Die navorsingsvraag wat hierdie artikel begrond, is: Hoe kan skoolleerders meer effektief in die skoolkurrikulum vir natuurwetenskappe onderrig word aangaande holistiese gesondheid? Alhoewel daar verwys word na drie navorsingstudies, is die artikel hoofsaaklik gegrond op 'n literatuuroorsig, en ek verskaf twee redes waarom holistiese gesondheidsorg nie tot sy reg in die skoolkurrikulum kom nie. Die navorsing waarna kortliks verwys word, is die volgende:

- 'n Etnobotaniese ondersoek onder die Khoisan-mense van die Agter-Hantam, Noord-Kaap (De Beer 2012). Dit is ' $n$ vinnige etnobotaniese taksering (rapid ethnobotanical appraisal), en die prosedures gevolg, is verder ontwikkel tot 'n praktiese metodologie wat die lewenswetenskappeonderwyser in die klaskamer kan gebruik.

- 'n Studie na die implementering van die Nasionale Kurrikulumverklaring vir lewenswetenskappe, vir die Gautengse Onderwysdepartement (De Beer \& Ramnarain 2012). In hierdie navorsing word verslag gedoen oor hoe 255 onderwysers die insluiting van inheemse kennis in die kurrikulum sien.

- 'n Studie onder 'n paar lewenswetenskappeonderwysers in Gauteng en Limpopo, aangaande die inkorporering van inheemse kennis in die klaskamer (De Beer \& Mothwa 2013).

\section{Is die doktrines aangaande die aard van die natuurwetenskappe in konflik met holisme en inheemse kennisstrukture?}

Vhurumuku (2010) identifiseer doktrines wat die aard van die natuurwetenskappe kenmerk:

- Dit is empiries.

- Wetenskaplike kennis is tentatief, dog sterk en bestendig (durable).

- Daar is 'n verskil tussen waarnemening en afleiding of gevolgtrekking.

- Alhoewel wetenskaplike kennis teoreties gebaseer is, is dit gedeeltelik subjektief.

- Verbeelding en kreatiwiteit speel 'n rol in die wetenskap.

- Daar is nie 'n enkele of absolute 'wetenskaplike metode' nie.

- Daar is 'n verskil tussen wet en teorie.

Op grond van hierdie doktrines argumenteer baie wetenskaplikes en natuurwetenskappe-onderwysers dat daar nie ruimte vir inheemse kennisstrukture in wetenskaponderrig is nie. Dikwels word voorgehou dat die wetenskap empiries is, en dat die 'natuurwetenskaplike metode' verseker dat wetenskap as epistemologie gekenmerk word deur objektiwiteit, en dat die natuur verklaar kan word aan die hand van fisies kousale wette en wetenskaplike modelle. Skrywers soos Louise Hay (2004) se standpunte aangaande die psigosomatiese aard van siektetoestande kan nie fisies kousaal verklaar word nie, en daarom ignoreer die meeste onderwysers haar werk. (Hay is van mening dat die meeste siektes psigosomaties van aard is; so byvoorbeeld is die emosionele oorsaak van diabetes ' $n$ bitterheid aangaande die lewe.)

In teenstelling met Vhurumuku se doktrines van die natuurwetenskappe, wys navorsers soos Jones en Hunter (2003) en Michie (2000) daarop dat inheemse kennis gekenmerk word deur die volgende wesenseienskappe:

- Inheemse kennis is gebaseer op ervaring.

- Dit is getoets deur eeue heen se gebruik.

- Dit is aangepas by die plaaslike kultuur en die omgewing.

- Dit is 'n dinamiese en veranderende lewende kennissisteem.

- Mondelinge oorlewering vind plaas, en inheemse kennis word dikwels metafories verwoord.

- Dit is nie moontlik om inheemse kennis te skei van etiek, spiritualiteit (geestelikheid), metafisika of die kulturele of seremoniële nie.

- Dit is holisties van aard (in teenstelling met die Westerse wetenskap wat dikwels reduksionisties is).

- Dit is gekontekstualiseer (in teenstelling met dikwels gedekontekstualiseerde Westerse wetenskap).

In Suid-Afrika maak die nasionale kurrikulum (die Kurrikulum- en assesserings-beleidsverklaring [KABV]) voorsiening vir die insluiting van inheemse kennis. Die Kurrikulum en assesseringsbeleidsverklaring is geskoei op 
sewe beginsels, waarvan een inheemse kennisstrukture is. Die KABV vir die Senior Fase Natuurwetenskappe (Departement van Basiese Onderwys 2011) stel dit duidelik dat:

Inheemse kennis sluit kennis van die volgende in: landbou en voedselproduksie, pastorale praktyke, diereproduksie, bosbou, plantklassifikasie, medisinale plante, die bestuur van biodiversiteit, voedselpreservering, die bestuur van grond en waterhulpbronne, smelt van yster, brou van bier, wonings en begrip van sterrekunde. Namate die samelewing verander het, het sommige van daardie kennis verlore gegaan. Mense soos bioloë, aptekers en argeoloë is op soek hierna en probeer dit aanteken sodat dit nie verlore kan gaan nie. (bl. 8)

De Beer en Van Wyk (2012) maak die stelling dat dit nie veel verbeelding verg om die verband tussen inheemse kennis en die moderne wetenskap te sien nie. Die outeurs is van mening dat inheemse kennis as ' $n$ vermiste skakel beskou kan word wat leerders kan help om meer volledige insig te bekom in die wetenskaplike denkpatroon en 'n meer diepsinnige insig in alledaagse konsepte. Wetenskaplike kennis en inheemse kennis, as twee verskillende epistemologieë, hoef dus nie in isolasie te bestaan nie: dit is moontlik om grense te oorbrug (border crossing), en sodoende die wetenskapkurrikulum meer relevant vir die leerders te maak.

Outeurs soos Hay (2004) en Morgan (2014) beskou welstand vanuit 'n holistiese perspektief. Laasgenoemde rapporteer oor navorsing wat gedoen is aangaande 'n holistiese welstandsprogram om MIV en/of VIGS-pasiënte by te staan. Die holistiese program van vier weke het tegnieke soos joga, terapeutiese dans, meditasie, reiki en refleksie ingesluit. $\mathrm{Na}$ afloop van die vier weke het al tien deelnemers verslag gedoen van die feit dat hulle kalmer voel, meer energie het, fisies beter voel en beter slaap, en ook meer selfvertroue het om die wêreld in die oë te kyk. 'n Ander studie (Cuneo et al. 2011) het gewys dat reiki suksesvol is om stres teen te werk, en so uitbranding te voorkom.

\section{Die affektiewe domein en inheemse kennisstrukture word in die wetenskappeklaskamer gemarginaliseer}

Ongelukkig realiseer $\min$ van hierdie inheemse kennisstrukture in die natuurwetenskappeklaskamer, 'n praktyk wat Odora Hoppers (2004) 'kennisapartheid' noem. Daar is drie redes hiervoor: eerstens beskik baie onderwysers nie oor die nodige kennis en vaardighede om inheemse kennis in te sluit in hulle onderrig nie; in die tweede plek beskou sommige onderwysers die insluiting van inheemse kennis in die natuurwetenskappe as pseudowetenskap (De Beer \& Van Wyk 2012), en in die derde plek lei die fokus op leerderprestasie en die eksamengedrewendheid tot 'n marginalisering van inheemse kennis, en die affektiewe domein (De Beer \& Ramnarain 2012). Dit is raadsaam om kortliks elk van hierdie redes van nader te bekyk.

\section{Onderwysers beskik nie oor die nodige kennis en vaardighede nie}

Onderwysers is nie noodwendig gekant teen die insluiting van inheemse kennis in die kurrikulum nie. In die navorsing wat ek vir die Gautengse Onderwysdepartement gedoen het (met 'n steekproef van 255 onderwysers) het baie onderwysers aangedui dat hulle die waarde van inheemse kennis insien (Sien Tabel 1). In 'n ondersoek van De Beer en Mothwa (2013) is aangetoon dat onderwysers egter nie oor die nodige kennis en vaardighede beskik om reg te laat geskied aan die inkorporering van inheemse kennis in die klaskamer nie. Onderwysers is nooit opgelei vir so 'n taak nie, en vanweë die groot kulturele diversiteit in die land, is dit dikwels moeilik om inheemse kennis in te sluit in 'n les, want wie se inheemse kennis gaan belig word? De Beer en Whitlock (2008) en De Beer en Van Wyk (2012) maak dit ook duidelik dat aandag aan inheemse kennis gegee kan word deur van wetenskaplike prosesse gebruik te maak. 'n Voorbeeld ter illustrasie: leerders kan 'n vinnige etnobotaniese taksering (rapid ethnobotanical appraisal) doen om vas te stel watter plante in ' $n$ bepaalde omgewing vir medisinale doeleindes gebruik word. Sulke plante kan dan in die klaskamer of skoollaboratorium getoets word vir antimikrobiale aktiwiteit, om vas te stel of daar enige wetenskaplike gronde is dat so 'n plant byvoorbeeld kan help vir'n seer keel. So byvoorbeeld kan leerders eenvoudige chromatografiese tegnieke aanleer om aktiewe bestanddele in die plant te ekstraheer, en plantekstrakte kan dan getoets word op agarmedia wat met bakterieë geïnokuleer is. Dit kan goedkoop en eenvoudig in die klaskamer gedoen word, deur byvoorbeeld soppoeier en gelatien te gebruik (in plaas van nutriëntagars), en sterilisasie kan effektief in 'n stoompot

TABEL 1: Lewenswetenskappe-onderwysers se antwoorde op die items aangaande inheemse kennis.

\begin{tabular}{|c|c|c|c|c|c|c|c|c|}
\hline \multirow[t]{2}{*}{ Item } & \multicolumn{2}{|c|}{ Verskil ten sterkste } & \multicolumn{2}{|c|}{$\begin{array}{l}\text { Stem nie heeltemal } \\
\text { saam nie }\end{array}$} & \multicolumn{2}{|c|}{ Stem gedeeltelik saam } & \multicolumn{2}{|c|}{ Stem absoluut saam } \\
\hline & $\boldsymbol{n}$ & $\%$ & $n$ & $\%$ & $n$ & $\%$ & $n$ & $\%$ \\
\hline $\begin{array}{l}\text { Deur na inheemse kennis te verwys word die } \\
\text { kurrikulum meer relevant vir my leerders }\end{array}$ & 4 & 1.7 & 27 & 11.7 & 140 & 60.9 & 59 & 25.7 \\
\hline $\begin{array}{l}\text { Leerders verstaan nie wetenskaplike konsepte nie, } \\
\text { omdat hulle vasklou aan inheemse kennis }\end{array}$ & 21 & 9.4 & 150 & 67.3 & 39 & 17.5 & 13 & 5.8 \\
\hline Die natuurwetenskap verklaar alle verskynsels ten volle & 17 & 7.6 & 115 & 51.3 & 75 & 33.5 & 17 & 7.6 \\
\hline $\begin{array}{l}\text { Daar is nie ' } n \text { skakel of verband tussen inheemse kennis } \\
\text { en die Westerse wetenskap nie }\end{array}$ & 21 & 9.4 & 142 & 63.4 & 51 & 22.8 & 10 & 4.5 \\
\hline $\begin{array}{l}\text { Inheemse kennis is dikwels in konflik met die Westerse } \\
\text { wetenskap }\end{array}$ & 1 & 0.5 & 82 & 38.0 & 111 & 51.4 & 22 & 10.2 \\
\hline
\end{tabular}

$n=255$. 
gedoen word, synde min skole, indien enige, oor 'n outoklaaf sal beskik. Sodanige benaderings stel egter eise in terme van voortgesette onderwysopleiding. Die Universiteit van Johannesburg het in 2013 begin met 'n kort leerprogram om onderwysers van natuurwetenskappe op te lei om inheemse kennis effektief in die klaskamer te betrek, en die resultate toon aan dat suksesvolle oordrag wel so plaasvind. (Dit is interessant [Tabel 1] om te sien dat baie onderwysers van mening is dat die natuurwetenskappe verskynsels ten volle kan verklaar word).

\section{Inheemse kennis is pseudowetenskap}

My betoog in hierdie artikel is nie vir pseudowetenskap nie. De Beer en Mothwa (2013) het bevind dat baie onderwysers van mening is dat inheemse kennis sinoniem is met pseudowetenskap, en dat dit daarom vermy moet word in die klaskamer. Die voorbeeld hierbo van 'n etnobotaniese ondersoek maak dit duidelik dat inheemse kennis met die nodige wetenskaplike strengheid en stiptelikheid ondersoek kan word. Leerders moet ook besef dat die wetenskap as epistemologie grense het, en soms kan die oorsteek van grense (border crossing) na die metafisika leerders bewus maak van die kompleksiteit van lewe, en dat wetenskaplike modelle partykeer onvoldoende blyk te wees om die lewe volkome te verklaar. Is daar enige wetenskaplike gronde vir die standpunte van Louis Hay dat emosies 'n invloed kan hê op gesondheid? Navorsing gedoen in die Center for Spirituality and Healing aan die Universiteit van Minnesota (2014) wys dat stres ' $n$ invloed het op die liggaam se hormoonbalans en ook lei tot chemiese versteurings. Dít lei weer tot gesondheidsprobleme soos hoë bloeddruk, kardiovaskulêre siektes en eetversteurings. Daar kan dus baie interessante gesprekke plaasvind in die natuurwetenskappeklaskamer oor die biologiese basis vir sulke psigosomatiese probleme.

Cronje, De Beer en Ankiewicz (n.d.) het 'n instrument ontwerp, die Menings van die Aard van Inheemse Kennis (Views of the Nature of Indigenous Knowledge), wat gebruik word as 'n instrument om te bepaal wat onderwysers se persepsies is aangaande inheemse kennis in die klas. Hierdie instrument is geskoei op die instrument van Abd-El-Khalick (1998), die Menings van die Aard van die Natuurwetenskappe (Views of the Nature of Science). Ten einde kort kursusse wat onderwysers se kennis en vaardighede ontwikkel in die onderrig van inheemse kennis te laat slaag, is dit belangrik om eers te bepaal hoe onderwysers inheemse kennis en die aard van natuurwetenskappe sien. Die bevindings aangaande die gebruik van hierdie instrument word in 'n ander publikasie belig.

\section{Die eksamengedrewendheid lei tot 'n marginalisering van affektiewe uitkomste}

In 2011/2012 is 'n studie gedoen vir die Gautengse Onderwysdepartement (De Beer \& Ramnarain 2012) oor die implementering van die nasionale kurrikulum in lewenswetenskappe en fisiese wetenskappe. Op die vraag of onderwysers voel dat hulle meer tyd sou wou hê om voor te berei vir hulle lesse, het 35.7\% (van 255 respondente) saamgestem met die stelling, en $52.9 \%$ het sterk saamgestem. Die oorgrote meerderheid (88.6\%) van die onderwysers het gevoel dat hulle onvoldoende tyd aan lesplanne spandeer, en die hoofrede wat aangevoer is, was die tyd wat aan assessering spandeer word. ' $n$ Volgende vraag in die vraelys het hierdie verskynsel bevestig. Op die vraag 'Wanneer ek 'n les beplan, is dit nodig om deur die assesseringstaak gelei te word', het $48 \%$ van die onderwysers saamgestem, en $34.5 \%$ het baie sterk saamgestem. Dus voel $82.5 \%$ van die onderwysers dat assesseringstake die belangrikste aspek is wat lesbeplanning beïnvloed. Ongelukkig word Suid-Afrikaanse skoolonderrig gekenmerk deur eksamengedrewendheid. 'n Onderwyser se sukses word verder gemeet aan die slaagsyfer, en dit lei daartoe dat die affektiewe domein nie tot sy reg kom nie. Die 'afrigting' vir die eksamen is veels te belangrik om aandag te gee aan die affektiewe domein, wat nie in die eksamen geëvalueer word nie.

\section{Die skoolkurrikulum moet op die adolessent se affektiewe ontwikkeling fokus}

Adolessensie is ' $n$ tydperk wanneer kinders worstel met persoonlike identiteit en die ontwikkeling van vaardighede om te oorleef in 'n veeleisende samelewing. Volgens navorsing is daar wêreldwyd 'n styging in stres en depressie onder adolessente (Leone, Ray \& Evans 2013). Depressiewe en angstige adolessente loop 'n groter risiko om probleemgedrag te openbaar; hulle ly aan 'n swak selfbeeld, en hulle skolastiese prestasie word negatief beïnvloed deur afwesigheid of gebrekkige konsentrasievermoë (Dia \& Bradshaw 2008). Dit is daarom belangrik dat daar in die kurrikulum op holistiese gesondheid gefokus word, maar soos reeds genoem, ly hierdie aspek skade vanweë die uitermate fokus op skolastiese prestasie soos gemeet in eksamens. Benewens die eksamengedrewendheid en die oordrewe fokus op die kognitiewe domein tot nadeel van die affektiewe uitkomste, is die aard van die natuurwetenskappe wat aan die leerders voorgehou word in die klaskamer problematies.

Opvoedende onderwys behoort gerig te wees op die leerder in sy totaliteit as mens. Daar moet dus te alle tye rekening gehou word met die leerder as tegelyk kognitiewe, affektiewe en psigomotoriese wese. Alhoewel hierdie drie fasette onderskeibaar is, is hulle terselfdertyd onskeibaar. Wetenskaponderwysers moet besef dat hulle moet rekening hou met die dimensies van ken (kognitiewe), kan (psigomotoriese) en gevoel (die affektiewe aspek) van die leerder. Die leerder beoefen die wetenskap as totale mens. Vir die realisering van affektiewe doelstellings in die klaskamer is dit nodig om kortliks na die taksonomie van Krathwohl, Bloom en Masia (1964) te kyk. Hierdie outeurs onderskei vyf kategorieë in die affektiewe domein, naamlik die ontvangs, respondering, waardering, organisasie en karakterisering van 'n waarde.

Dit is essensieel om leerders bewus te maak van holistiese gesondheidsbeginsels in die klaskamer sodat hulle die rol van die natuurwetenskappe in ons daaglikse lewes 
kan waardeer; en in hierdie spesifieke konteks, om welstand en gesondheid holisties te sien en te waardeer. Ongelukkig gebeur dit dikwels nie, omdat alternatiewe gesondheidsorg - dink maar aan reiki, aromaterapie, akapunktuur en homopatie - as 'onwetenskaplik' beskou word, en eerder as metafisika gesien word, en nie as natuurwetenskappe nie.

\section{Krathwohl se klassifikasie van die affektiewe domein}

Die klassifikasiesisteem van Krathwohl et al. (1964) is 'n klassieke werk wat ongelukkig nog nooit tot sy reg gekom het nie. Benewens die eksamengerigtheid wat ons onderwys kenmerk, is 'n verdere rede vir die marginalisering van die affektiewe domein dat dit moeilik is om affektiewe uitkomstes te assesseer. Hoe evalueer 'n onderwyser 'n leerder se gesindheid, en hoe word daar punte gegee aan deursettingsvermoë wanneer 'n eksperiment gedoen word? Myns insiens moet ons in die onderwys opnuut besin oor hoe die affektiewe sentraal gestel kan word. Hieronder volg 'n kort sinopsis van Krathwohl et al. (1964) se klassifikasiesisteem. Die outeurs onderskei 'n getal subkategorieë op elke vlak, maar vir die doel van hierdie artikel word net die vyf hoofvlakke genoem.

\section{Vlak 1.0. Ontvangs of reseptiwiteitskategorie}

Op hierdie vlak word daar van die leerder verwag om sensitief te wees vir die bestaan van bepaalde fenomene of verskynsels. Die leerder moet dus bereid wees om hom vir 'n stimulus oop te stel.

\section{Vlak 2.0. Respondering}

Op hierdie vlak gaan dit om meer as om bloot net aandag te gee aan of die persepsie van 'n stimulus. Hier is die leerders in so ' $n$ mate gemotiveerd dat hulle aktief deelneem. Hierdie kategorie is die vlak wat onderwysers se 'belangstellingsdoelstellings' omvat.

\section{Vlak 3.0. Waardebelewingskategorie}

Op hierdie vlak val die klem op die verinnerliking of verpersoonliking van sekere waardes. Die leerder aanvaar dat die begrip waarde en nut inhou.

\section{Vlak 4.0. Organisasie in ' $n$ waardesisteem}

Soos leerders stelselmatig waardes internaliseer, kom hulle te staan voor situasies waar meer as een waarde moontlik relevant kan wees. Dit word dus nou nodig om waardes in 'n sisteem te begin organiseer, die verwantskappe tussen waardes te bepaal en die dominante en deurdringende waardes in 'n sisteem te vestig. So 'n sisteem word geleidelik opgebou en is onderhewig aan verandering namate nuwe waardes geïnkorporeer word. Die leerder moet op hierdie vlak byvoorbeeld ' $n$ eie opinie of oordeel vorm aangaande welstand, en die individu se verantwoordelikheid om goeie keuses uit te oefen om liggaamlike en geestelike gesondheid te verseker.

\section{Vlak 5.0. Karakterisering deur 'n waardekompleks of internalisering}

Hier beskik die persoon oor 'n lewensfilosofie wat die verskillende aspekte van sy lewe integreer. Daar is op hierdie vlak sprake van die integrasie van idees en gesindhede in 'n wêreldbeskouing. Waardes het dus nou'n plek in die individu se hiërargie van maatstawwe, en dit is georganiseer in 'n interne sisteem. Karakter omvat die keuses wat die individu maak. Op hierdie vlak van karakterisering word deurgedring na 'n persoon se lewensfilosofie - sy 'Weltanschauung'. In 'n natuurwetenskappeklas beteken dit dat, wanneer daar na patogene gekyk word, 'n leerder ook sal besef dat sy keuses in terme van gesondheidsorg 'n deurslaggewende rol speel.

Hauptfleisch (1986) wys daarop dat daar 'n verwantskap bestaan tussen die affektiewe domein, en die bereiking van kognitiewe doelwitte (Tabel 2).

In die artikel is gepoog om 'n begronding te verskaf vir die insluiting van affektiewe doelstellings in die klaskamer,

TABEL 2: Die verwantskap tussen die affektiewe en kognitiewe domeine.

\section{Affektiewe domein}

Reseptiwiteit

Persepsie

Bereidheid tot reseptiewe gedrag

Selektiewe gedrag

Respondering

Toegewing aan responsie

Bereidheid tot responsie

Voldoening aan responsie

Waardebelewing

Aanvaarding van 'n waarde

Voorkeur vir' $n$ waarde

Identifikasie met ' $n$ waarde

Organisasie

Begripmatige verwerking van ' $n$ waarde

Opbou van 'n waardesisteem

Karakterisering

Samehangende geheel van waardes

Volkome integrasie van waardes
Kognitiewe domein (volgens De Block 1975)

Weet (sekere aandag vir)

Insien (aanvoeling) 
en die bewusmaking onder leerders dat gesondheidsorg vanuit ' $n$ holistiese perspektief gesien moet word. Deur leerders bewus te mak van die meer metafisiese aspekte van welstand, en die belangrikheid van gesonde keuses (die reseptiwiteitkategorie), sal leerders hulself hopelik oopstel om meer hieroor te leer, en uiteindelik sal hulle waarde heg aan sodanige keuses.

\section{Hoe inheemse kennis se insluiting in die kurrikulum 'n holistiese beskouing van welstand kan bevorder}

Wanneer daar gekyk word na inheemse kennis vanuit 'n tradisionele genesingsperspektief, is dit belangrik om te onderskei tussen twee kategorieë van tradisionele genesers:

- Die geestelike geneser (diviner) (of, soos dit in die volksmond bekend is, sangoma), wat 'n diagnose gewoonlik maak op grond van 'n spirituele manifestasie of proses (in sommige kulture deur met die voorvadergeeste kontak te maak).

- Die kruie- of bossiedokter, wat plant- en dierprodukte as medisyne voorskryf.

In hierdie artikel het ek gewys hoe laasgenoemde op wetenskaplike manier betrek kan word in die klaskamer, en hoe leerders die prosesse van die Westerse wetenskap kan gebruik om die aansprake van moetiemedisyne te toets. Deur van ' $n$ etnobotaniese taksering en dan van wetenskaplike prosesse soos chromatografie en mikrobiologiese antimikrobiale tegnieke gebruik te maak, kan leerders sulke hipoteses (dat 'n bepaalde plant kan help vir 'n bepaalde siektetoestand, omdat dit patogene teenwerk) in die laboratorium toets. Inheemse kennis sluit egter ook die paljas-element (die metafisiese aspek) in, en die Westerse wetenskap sal dit waarskynlik nooit erken of kan verklaar nie. Dit is egter onlosmaaklik deel van inheemse kennissisteme. Voorbeelde hiervan uit die Khoisankultuur sluit die gebruik in van boegoemengsels (Agathosma betulina) by Xam-reënmaking (Low 2004). In teenstelling met hierdie paljasgebruik van boegoe, is daar egter ook baie wetenskaplike bewyse vir die mediese gebruik van die Agathosma-spesies in die behandeling van niere en urinêre siektes (Van Wyk, Van Oudtshoorn \& Gericke 1997). Die waarde van hierdie metafisiese aspek van inheemse kennis, is dat dit leerders sensitief kan maak daarvoor dat welstand uit 'n holistiese perspektief gesien moet word. Vrugbare besprekings kan plaasvind in die klaskamer aangaande alternatiewe gesondheidsorg soos byvoorbeeld reiki, en watter mediese gronde daar bestaan vir sulke alternatiewe behandeling. Die betoog hier is nie dat sulke uitsprake summier aanvaar moet word nie, maar eerder dat leerders bewus gemaak moet word daarvan, en dat hulle tydens hulle literatuurnavorsing sal besef dat die mediese wetenskap soms stom staan teenoor alternatiewe behandelings wat suksesvol blyk te wees.

\section{Samevatting en gevolgtrekking}

Adolessente beleef geweldig baie druk in 'n veeleisende samelewing, en die kurrikulum vir die natuurwetenskappe behoort die leerders toe te rus om gesondheidsorg holisties te sien. Jong mense moet weet hoe stres verminder kan word, en hoe vandag se besluite aangaande lewenstyl in hulle latere lewens 'n invloed kan hê op lewenskwaliteit. Dit stel hoë eise aan die natuurwetenskappe- en lewenswetenskappekurrikula. In hierdie artikel het ek twee vermiste skakels in dié verband bespreek, naamlik die kurrikulum wat gesondheidsorg vanuit 'n baie reduksionistiese perspektief sien, en wat leerders nie die leergeleentheid bied om waardering vir die holistiese aard van gesondheidsorg te ontwikkel nie. Tweedens word die affektiewe domein in die natuurwetenskappeklaskamer dikwels gemarginaliseer. Een manier om die affektiewe 'n sterker fokus te laat kry, is om inheemse kennis in te voer in die skoolkurrikulum. Inheemse, tradisionele geneeskunde kyk holisties na die mens se gesondheid, en dit is juis hierdie holisme, en die metafisiese komponent wat ook ter sprake is, wat sommige kurrikulumspesialiste ongemaklik maak. Dit is egter moontlik om die grense van die metafisika te verken in die klaskamer vir natuurwetenskappe, sonder om pseudowetenskap te bedryf. Dit vra egter besondere kundigheid van die onderwyser, en dat sodanige kennis en vaardigheid ontwikkel moet word tydens professionele ontwikkelingsprogramme, waar nodig.

\section{Erkenning}

Die outeur bedank twee van sy nagraadse studente wat werk in hierdie veld, Melida Mothwa, en Annelize Cronje, na wie se navorsing in die artikel verwys word. Spesiale dank word ook gerig aan Ben-Erik van Wyk van die Departement Plantkunde en Plantbiotegnologie, saam met wie ek veldwerk onder die Khoisanmense in die Noord-Kaap gedoen het. Laastens wil ek die Universiteit van Johannesburg bedank vir die befondsing wat dié navorsing moontlik gemaak het.

\section{Mededingende belange}

Die outeur verklaar hiermee dat hy geen finansiële of persoonlike verbintenis het met enige party wat hom nadelig of voordelig kon beïnvloed het in die skryf van hierdie artikel nie.

\section{Literatuurverwysings}

Abd-El-Khalick, F., 1998, 'The influence of history of science courses on students' conceptions of the nature of science', Unpublished doctoral thesis, Oregon State University, Corvalis, OR

Center for Spirituality and Healing, 2014, 'Taking charge of your health wellbeing', University of Minnesota, viewed 22 May 2014, from http://www.takingcharge. csh.umn.edu/enhance-your-wellbeing/health/thoughts-emotions/how-dothoughts-emotions-impact-health

Collinge, W., 1996, The American Holistic Health Association Complete guide to alternative medicine, Warner Books, New York.

Cowling, W.R., 2014, 'Reflections on holism and the passing of Nelson Mandela', Journal of Holistic Nursing 32(1), 4-5. http://dx.doi.org/10.1177/0898010113520127

Cronjé, A., De Beer, J. \& Ankiewicz, P., n.d., 'Development of an instrument to determine science teachers' views on indigenous knowledge', unpublished (article under review).

Cuneo, C.L., Cooper, M.R., Drew, C., Naoum-Heffernan, C., Sherman, T. \& Walz, K., 2011 , 'The effect of Reiki on work-related stress of the registered nurse', Journal of Holistic Nursing 29(1), 33-43.http://dx.doi.org/10.1177/0898010110377294

De Beer, J.J.J., 1990, 'Die affektiewe dimensies in Biologie-onderwys', ongepubliseerde M.Ed.-verhandeling, Randse Afrikaanse Universiteit, Johannesburg.

De Beer, J.J.J., 2012, 'An ethnobotanical survey of the Agter-Hantam, Northern Cape Province, South Africa', M.Sc. dissertation, University of Johannesburg, Johannesburg. 
De Beer, J.J.J. \& Mothwa, M., 2013, 'Indigenous knowledge in the science classroom: Science, pseudo-science or a missing link?', ISTE International Conference on Mathematics, Science and Technology Education: Towards effective teaching Mathematics, Science and Technology Education: Towards effective teaching and meaningful learning in Mathemal

De Beer, J. \& Ramnarain, U., 2012, 'The implementation of the FET Physical- and Life Sciences curricula: Opportunities and challenges', Research Report prepared for the Gauteng Department of Education (ISBN 978-0-86970-721-0).

De Beer, J. \& Van Wyk, B.E., 2012, 'Inheemse kennis in die lewenswetenskappeklaskamer: Wetenskap, pseudo-wetenskap, of ' $n$ vermiste skakel?', Suid-Afrikaanse Tydskrif vir Natuurwetenskap en Tegnologie 31(1), 119-123. http://dx.doi.org/10.4102/satnt.v31i1.368

De Beer, J. \& Whitlock, E, 2008, 'Indigenous knowledge in the life sciences classroom Put on your De Bono hats', The American Biology Teacher 71(4), 209-216. http:// dx.doi.org/10.1662/005.071.0407

De Block, A., 1975, Taxonomie van leerdoelen, Standaard wetenschappelijke uitgeverij, Amsterdam.

Departement van Basiese Onderwys, 2011, Kurrikulum- en assesseringsbeleidsverklaring Natuurwetenskappe Senior Fase, Staatsdrukkery, Pretoria.

Dia, D.A. \& Bradshaw, W., 2008, 'Cognitive risk factors to the development of anxiety and depressive disorders in adolescents', Child and Adolescent Social Work Journal 25, 469-481. http://dx.doi.org/10.1007/s10560-008-0156-7

Hauptfleisch, H., 1986, 'Affektiewe oorwegings by kurrikulering vir adolessente', (M.Ed.-verhandeling), Randse Afrikaanse Universiteit, Johannesburg.

Hay, L.L., 2004, You can heal your life, Hay House Inc., London.
Jones, M.E. \& Hunter, J., 2003, 'Enshrining indigenous knowledge in the national sciences curriculum: Issues arising from the Maori case', RCSD Conference at Chang Mai University, Thailand, July 2003.

Krathwohl, D.R., Bloom, B.S. \& Masia, B.B., 1964, Taxonomy of educational objectives, Handbook 2: Affective domain, Longmans, London.

Leone, D.R., Ray, S.L. \& Evans, M.E., 2013, 'The lived experiences of anxiety among late adolescents during high school', Journal of Holistic Nursing 31(3), 188-197. http://dx.doi.org/10.1177/0898010113488243

Low, C., 2004, 'Khoisan healing: Understandings, ideas and practices', unpublished D.Phil. thesis, University of Oxford, Oxford.

Michie, M., 2000, 'Providing teacher support materials for curriculum developments incorporating intercultural understanding in teaching science', $31^{\text {st }}$ Annual Conference of the Australian Science Education Research Association, Fremantle, July 2000

Morgan, V., 2014, 'The feasibility of a holistic wellness program for HIV/AIDS patients residing in a voluntary inpatient program', Journal of Holistic Nursing 32(1), 5460. http://dx.doi.org/10.1177/0898010113489178

Odora Hoppers, C.A., 2004, 'Culture, indigenous knowledge and development', Conference on Development Priorities and the Role of Tertiary Education, Wilton Park, UK, March 2004.

Smuts, J., 1926, Holism and evolution, Macmillan, New York.

Van Wyk, B.-E., Van Oudtshoorn, B. \& Gericke, N., 1997, Medicinal plants of South Africa, Briza Publications, Pretoria.

Vhurumuku, E., 2010, 'Using scientific investigations to explain the nature of science', in U. Ramnarain (ed.), Teaching Scientific Investigations, n.p., Macmillan, Johannesburg. 